\title{
STRATEGI SUMBER DAYA MANUSIA: STUDI EKSPLORASI DI MADRASAH TSANAWIYAH SWASTA JAGAT RAYA, DESA KEDONGDONG, KABUPATEN CIREBON-INDONESIA
}

HUMAN RESOURCE STRATEGY: EXPLORATION STUDY IN MADRASAH TSANAWIYAH PRIVATE VOCATIONAL SCHOOL, JAGAT RAYA, DESA KEDONGDONG, CIREBON-INDONESIA DISTRICT

\author{
Nurkholifatul Maula \\ Universitas Negeri Yogyakarta \\ Kampus Karangmalang-Jl. Colombo No. 1 Depok, Sleman Yogyakarta \\ Email: maulanurkholifatul89@gmail.com
}

\begin{abstract}
The polemic of private schools has quite been a debate in Indonesia. There are many private schools with good quality in Indonesia that make their existence beat the public schools. However, it is inversely proportional to the private school in the village. Private schools in the village are quite alarming. This study aims to describe about human resources strategy in Jagat Raya school and the effect of human resources strategy on the school development. This study employed exploratory methods. In this case, the exploratory methods used to were interview methods, observation and document studies. This first objective was done by conducting interviews and direct observation. The second objective of this study was conducted by using document review. The result of this research, in terms of organization, on vision and mission planning, was conducted by discussing together with the teachers at school. The impact of the human resource strategy, in terms of the student quality during the last five years is quite increasing, and the national exam scores are quite improving from year to year. However, it is inversely proportional to the decreased number of students who enter each year. This condition is quite critical for the sustainability of the school.
\end{abstract}

Keywords: Human Resources Strategy, Privat School, Student, Teacher.

\begin{abstract}
Abstrak
Polemik sekolah swasta selama ini cukup menjadi perdebatan di Indonesia.Cukup banyak sekolah swasta yang memiliki kualitas bagus di Indonesia, hingga eksistensinya pun mengalahkan sekolah negeri. Akan tetapi, hal itu berbanding terbalik dengan sekolah swasta di desa. Sekolah swasta di desa cukup memprihatinkan.Penelitian ini bertujuan untuk mndeskripsikan mengenai startegi sumberdaya manusia di MTs Jagat Raya dan dampak dari strategi sumberdaya manusia terhadap perkembangan sekolah. Pada hal ini, metode eksploratori digunakan dengan metode wawancara, observasi, dan kajian-kajian dokumen.Tujuan pertama ini, dengan melakukan wawancara dan observasi langsung.Tujuan kedua penelitian ini dilakukan dengan menggunakan kajian dokumen. Adapun hasil dari penelitian ini adalah dalam hal organization, pada perencanaan visi dan misi, dilakukan dengan musyawarah bersama dengan guru-guru di sekolah.Adapun dampak dari strategi sumber daya manusia tersebut, dari segi kualitas siswa nya selama lima tahun terakhir cukup meningkat, dan nilai ujian nasionalnya cukup membaik dari tahun ke tahun. Akan tetapi, hal ini berbanding terbalik dengan jumlah siswa yang masuk setiap tahunnya mengalami penurunan. Hal ini cukup kritis untuk keberlanjutan sekolah tersebut.
\end{abstract}

Kata Kunci: Strategi sumber daya manusia, sekolah swasta, siswa, guru.

\section{PENDAHULUAN}

Eksistensi sekolah swasta semakin

meningkat di era modernisasi sekarang.

Serta menjamurnya sekolah-sekolah swasta

di setiap desa memudahkan akses

pendidikan bagi masyarakat desa. Akhir- akhir ini pun, banyak sekolah swasta yang memliki reputasi dan kualitas yang cukup baik. Akan tetapi, sebagian besar dari sekolah swasta tersebut hanya mampu dirasakan oleh masyarakat kalangan atas. Dikarenakan biaya yang cukup tinggi. 
Kasus lain pada sekolah swasta di desa yang mayoritas memang memiliki pembiayaan yang sangat murah, bahkan gratis. Sekolah tersebut menjadi sebuah alternatif bagi masyarakat desa untuk melanjutkan sekolah ke jenjang yang lebih tinggi. Akan tetapi, mayoritas sekolah swasta yang seperti itu berbanding lurus dengan kualitas sekolah. Faktanya, masih cukup banyak sekolah swasta di Indonesia yang mengalami krisis siswa dengan adanya jumlah siswa yang semakin menurun dari tahun ketahun. Berdasarkan hasil dari observasi langsung peneliti, salah satu contoh eksistensi sekolah swasta di wilayah Yogyakarta yang mengalami krisis jumlah siswa. Hal tersebut dikarenakan kurangnya prestasi siswa dan masyarakat menilai bahwa sudah banyak sekolah swasta yang memiliki kualitas bagus. Sehingga masyarakat lebih memilih sekolah swasta yang telah memiliki eksistensi baik dimata masyarakat.

Berdasarkan problematika diatas, hal tersebut tidak sejalan dengan penelitian dari James Tooley (2009) mengenai sekolah swasta di India yang memberikan pelayanan bagus dengan biaya yang sangat rendah. Hal yang cukup mengagetkan dari penelitian James Tooley ialah sekolah swasta di India dengan sarana prasarana sekolah yang sama sekali tidak memadai, bahkan ada beberapa sekolah hanya memiliki satu ruangan serta hampir roboh dan memang mayoritas sekolah swasta murah di India cukup sangat memprihatinkan jika dilihat secara fisik. Namun, hal yang menjadi paling optimis ialah semangat guru dan semangat siswa di dalamnya. guru - guru di sana memiliki semangat untuk terus memberikan pengajaran terbaik meski memiliki gaji kecil. Begitupun juga dengan semangat siswa dan prestasi mereka yang cukup mengagumkan. Melihat output yang bagus, masyarakat India lebih mempercayai anaknya untuk disekolahkan di sekolah swasta jika dibandingkan dengan sekolah negeri.

Akhir-akhir ini, sekolah swasta menjadi kompetitor sekolah negeri. Seiring dengan permintaan masyarakat yang lebih mementingkan kualitas sekolah meskipun berbiaya tinggi. Tetapi, masih banyak juga sekolah swasta yang menyediakan pelayanan bagus dengan biaya murah. Pada dasarnya, fenomena sekolah swasta dilndonesia sebagai upaya untuk pemerataan pendidikan bagi seluruh siswa. Terlebih siswa miskin. Seperti yang dilansir dari berita detik.com (diakses pada tanggal 3 Januari 2018) kepala Dinas Pendidikan Jawa Barat sudah ditetapkannya kuota miskin bagi masing-masing sekolah swasta.

Merujuk pada hasil penelitian dari James Tooley mengenai kondisi sekolah swasta di India, sangat berbanding terbalik dengan kondisi sekolah swasta di Indonesia. Berdasarkan observasi pribadi peneliti, salah satu sekolah swasta di kota Yogyakarta mengalami krisis siswa dikarenakan sekolah swasta yang sulit untuk beradaptasi dengan perubahan kebijakan pemerintah. Berbagai berita mengenai krisis siswa di sekolah swasta pun akhir-akhir ini 
menjadi sebuah eksistensi baru serta tantangan yang cukup riskan bagi sekolah swasta.

Merujuk kembali pada berita mengenai jumlah siswa di sekolah swasta yang semakin menurun di daerah cirebon yang dilansir dari kabar-cirebon.com (diakses pada tanggal 3 Januari 2018) sebanyak 14 SMA dan 27 SMK swasta di Cirebon mengalami kondisi sama dengan jumlah calon siswa masih dibawah 100. Bahkan masih ada sekolah yang baru hanya menerima 12 siswa. Hal tersebut membuat sekolah swasta merasa resah terhadap kelanjutan sekolah tersebut.

Berdasarkan berbagai permasalahan yang telah dipaparkan diatas, eksistensi sekolah swasta tidak terlepas dari kepemimpinan suatu kepala sekolah atau manajer. Sekolah merupakan suatu sistem yang terdiri dari input, proses, dan output, yang mana pada semua sistem tersebut intinya yaitu mengolah suatu sumber daya manusia. Dalam mengolah sumber daya manusia, tentunya bukan suatu pekerjaan yang mudah bagi suatu lembaga. Melainkan tantangan dan suatu permasalahan yang serius bagi lembaga tersebut.

Merujuk pada pendapat dari Mahapatro (2010) mengungkapkan pentingnya sebuah manajemen sumber daya manusia.

"The human resources are assuming increasing significance in modern organizations. Obviously, majority of the problem organizational setting are human and social rather than physical, technical or economic. The significance of human

resources can be examined from time to time."

Berdasarkan pendapat dari Mahapatro, sumber daya manusia berpengaruh secara signifikan dalam peningkatan organisasi modern. Karena sebagian besar masalah pengaturan organisasi ialah manusia dibandingkan secara fisik dan mekanik. Organisasi modern lebih berfokus pada kualitas dan efektivitas suatu sumber daya manusia di suatu lembaga. Manajemen sumber daya manusia yang baik, akan menghasilkan suatu kinerja yang baik pula. Sehingga dapat meningkatkan kualitas dan eksistensi sebuah lembaga atau organisasi.

Pada kemajuan zaman saat ini, mulai berkembang suatu disiplin ilmu yang membahas mengenai strategi sumber daya manusia bagi pemimpin atau kepala sekolah. Pada dasarnya strategi merupakan suatu cara untuk menyusun kegiatankegiatan yang akan dilakukan suatu organisasi untuk mencapai tujuannya. Strategi sumber daya manusia merupakan suatu strategi yang digunakan untuk mengelola dan mengatur sumber daya manusia yang ada di suatu lembaga pendidikan.

Berdasarkan pendapat dari Michael Armstrong (2006) definisi strategi sumber daya manusia ialah sebagai berikut:

"Strategic Human Resources
Management (HRM) is a process that
involves the use of overarching
aproaches to the development of HR
strategies, which are integrated vertically
with the bussines strategy and
horizontally with one another. These


strategies define intentions and plans related to overall organizational considerations, such as organizational effectiveness, and to more specific aspects of people management, such as resourcing, learning, and development, reward and employee relations."

Berdasarkan penjelasan dari Armstrong, strategi sumber daya manusia melibatkan seluruh elemen yang ada pada lembaga pendidikan. Adapun cakupan dari strategi sumber daya manusia yaitu dimulai dari rencana pertimbangan organisasi secara keseluruhan, keefektifan organisasi, dan aspek pengelolaan sumber daya seperti: sumber daya, pembelajaran, pengembangan, penghargaan dan hubungan karyawan.

Merujuk pada aspek-aspek yang ada pada strategi sumber daya manusia, tentunya menjadi sebuah keharusan suatu sekolah swasta untuk memperbaiki secara internal lembaganya. Hal tersebut bertujuan juga untuk mempertahankan eksistensinya dalam menghadapi krisis jumlah siswa yang semakin menurun.

Sejalan dengan berita terkait di kabupaten Cirebon yang menyatakan bahwa tantangan sekolah swasta saat ini ialah dengan jumlah siswa yang semakin menurun. Salah satu sekolah swasta yang dijadikan sampel pada penelitian ini ialah sekolah swasta Madrasah Tsanawiyah (MTs) Jagat Raya di desa Kedongdong, kecamatan Susukan, kabupaten Cirebon. Sekolah tersebut mengalami krisis jumlah siswa yang semakin menurun. Siswa yang ada pada sekolah MTs Jagat Raya hanya berasal dari wilayah sekitar atau dari desa Kedongdong dan sekitarnya saja. Penelitian ini penting dilakukan untuk mengetahui bagaimana cara MTs Jagat Raya melakukan strategi sumber daya manusia di sekolah tersebut dan dampak dari strategi sumber daya manusia yang dipakai oleh kepala sekolah MTs Jagat Raya terhadap perkembangan MTs Jagat Raya.

Penelitian mengenai strategi sumber daya manusia sangat penting dilakukan pada sekolah swasta. Hal ini berguna bagi sekolah swasta lainnya untuk mengembangkan strategi sumber daya manusia yang dipakainya. Penelitian ini sejalan dengan pendapat dari Michelsen and Wells (2017) menyatakan bahwa selama tahun 1990 an, UNESCO telah mengidentifikasi beberapa hal yang mempengaruhi berkelanjutannya suatu sekolah atau sekolah tersebut bertahan pada eksistensinya. Diantara hal yang mempengaruhi tersebut ialah: istitusi dan pendidik yang merupakan kunci utama.

UNESCO telah mengembangkan guru-guru dan orientasi pelatihan para guru yang hanya bertujuan untuk meningkatkan kualitas guru sehingga dapat mempertahankan eksistensi suatu sekolah. Orientasi guru-guru erat kaitannya dengan strategi sumber daya manusia yang dilakukan oleh kepala sekolah.

\section{METODE PENELITIAN}

Pada penelitian ini, peneliti menggunakan model eksploratori studi dengan pendekatan kualitatif deskriptif. Merujuk pendapat dari Sulipan (2010) penelitian eksploratori bertujuan untuk mengeksplor 
segala informasi atau aktivitas yang menyangkut tema penelitian ini.

Penelitian ini dilakukan disatu sekolah yaitu MTs Jagat Raya di desa Kedongdong, kecamatan Susukan, kabu-paten Cirebon. Peneliti memilih MTs Jagat Raya dikarenakan beberapa alasan, yaitu: MTs Jagat Raya merupakan salah satu MTs Swasta yang berada di desa dan sedang mengalami masa kritis karena jumlah siswa yang fluktuatif, serta siswa yang hanya berasal dari sekitar desa tersebut. Karena hal ini perlu adanya penelitian mendalam mengenai strategi sumber daya manusia yang dipakai pada MTs Jagat Raya dan dampaknya terhadap kualitas serta eksistensi sekolah. Hasil dari penelitian ini pun dapat digunakan sebagai perbaikan strategi sumber daya manusia di sekolah swasta.

Penelitian ini dilakukan selama tiga bulan. Dimulai pada tanggal 3 Juni 2017 sampai dengan 10 Agustus 2017. Bulan Juni peneliti melakukan pra riset atau observasi secara menyeluruh, pada bulan Juli, peneliti melakukan riset dari hasil observasi umum MTs Jagat Raya, dan pada bulan Agustus peneliti melakukan analisis serta membuat laporan.

Adapun teknik pengumpulan data, peneliti menggunakan beberapa teknik. Diantaranya yaitu: wawancara, observasi atau pengamatan langsung, dan studi literatur berdasarkan dokumen-dokumen primer maupun sekunder. Wawancara langsung bertujuan untuk mencari informasi mengenai strategi yang dilakukan oleh kepala sekolah, dan wawanacar pun dilakukan untuk mengetahui respon dan keadaan sebenarnya dari para guru dan siswa. Observasi dilakukan guna mengamati kegiatan keseluruhan dari kegiatan belejar mengajar, serta kegiatan keseharian di sekolah. Kajian dokumen primer ini digunakan pada dokumen-dokumen dari MTs Jagat Raya yang meliputi: profil MTs Jagat Raya, dokumen guru dan siswa. Dokumen tersebut bertujuan sebagai pendukung dan bahan untuk menyelaraskan serta mengukur ketercapaian MTs Jagat Raya berdasarkan strategi sumber daya manusia yang dpakai.

Analisis data pada penelitian ini dengan menggunakan metode Miles and Huberman (1994) dalam Creswell (2015:252) menyatakan bahwa Miles and Huberman menyediakan langkah yang lebih detail dalam proses tersebut.

Selain menggunakan analisis Miles and Huberman, peneliti juga menggunakan teknik analisis SWOT (Strengths, Weakness, Opportunities, dan Threats). Dikutip dari Fajar Nur'ani $(2016,7)$ adapun pengertian dari teknik analisis SWOT merupakan suatu metode yang digunakan untuk mengevaluasi kekuatan (Strengths), kelemahan (weakness),peluang (opportunities), dan ancaman (threats) dalam suatu spekulasi lembaga. Beberapa ahli menyebutkan bahwa analisis SWOT merupakan sebuah instrumen perencanaan strategik klasik yang memberikan cara sederhana untuk memperkirakan cara terbaik dalam menentukan sebuah strategi. 
Lebih dalam lagi, Sugiyono (2016:337) menjelaskan mengenai metode analisis Miles and Huberman bahwa aktivitas dalam analisis data kualitatif dilakukan secara interaktif dan berlangsung secara terus menerus sampai tuntas. Adapun langkahlangkah dalam metode Miles and Huberman yaitu: periode pengumpulan data, reduksi data, display data, dan kesimpulan atau verifikasi.

Adapun langkah-langkah pengembangan metode Miles and Huberman pada penelitian ini adalah sebagai berikut:

\section{Tahap pengumpulan data}

Tahap pengumpulan data, peneliti melakukan wawancara dan menggali beberapa informasi dari dokumen serta melakukan observasi mengenai strategi sumber daya manusia di MTs Jagat Raya.

\section{Reduksi Data}

Setelah mendapatkan banyak data, peneliti mereduksi data-data yang didapat dari pengumpulan data yang sesuai dengan tema penelitian. Pada tahap ini, peneliti memilih data-data pokok dan membuang yang tidak perlu.

\section{Penyajian Data}

Pada penyajian data dilakukan dalam bentuk uraian singkat sesuai dengan rumusan masalah yang telah ditentukan.

Setelah penyajian data, akan dicermati dan dipahami oleh peneliti, hal itu digunakan untuk menentukan langkah selanjutnya.

4. Penarikan kesimpulan dan verifikasi data
Pada satu tahap ini, peneliti menarik kesimpulan sementara. Karena kesimpulan tersebut akan diverifikasi kebenarannya dan disesuaikan dengan bukti-bukti yang ada. Begitupun selanjutnya, akan terjadi interaksional antara langkah-langkah tersebut.

\section{HASIL DAN PEMBAHASAN}

STRATEGI SUMBER DAYA MANUSIA DI MTS JAGAT RAYA

Pada strategi sumber daya manusia di MTs jagat Raya, terdapat beberapa variabel yang menjadi landasan utama pada penelitian ini. diantaranya yaitu: visi dan misi sekolah, strategi kepala sekolah dan kesesuaian visi, misi, serta strategi dengan kedaan di sekolah. Strategi sumber daya manusia mencakup beberapa hal yaitu: rekrutmen guru dan pengembangan guru.

Sebelum membahas lebih jauh mengenai strategi sumber daya manusia di MTs Jagat Raya, penting untuk diketahui mengenai profil jelas dari MTs Jagat Raya. Hal ini untuk melihat adanya konsistensi antara visi dan misi serta strategi yang dilakukan oleh kepala sekolah.

MTs jagat Raya pada awal berdirinya tidak terlepas dari perkembangan pondok pesantren Jagat Raya. Yayasan pondok pesantren Jagat Raya telah didirikan pada tahun 1995, pada mulanya mendirikan taman kanak-kanak dan lembaga sosial anak. Memperhatikan animo masyarakat pada waktu itu yang cukup baik tentang pendidikan agama di wilayah desa Kedongdong, akhirnya didirikanlah MTs 
Jagat Raya pada tahun 2002, hingga sekarang akreditasi MTs Jagat Raya sangat baik atau dikonversikan menjadi nilai "A". Artinya, MTs Jagat Raya telah memenuhi delapan standar nasional pendidikan.

Adapun visi dari MTs jagat Raya ialah dengan berpedoman pembentukan akhlakul karimah, mewujudkan Madrasah Tsanawiyah (MTs) Jagat Raya sebagai MTs Kebanggaan masyarakat. Bukan hanya menyusun sebuah visi yang masih mentah, akan tetapi MTs Jagat Raya menyusun beberapa indikator dari visi tersebut. Diantara indikatornya ialah:

1. Terbentuknya pribadi yang berilmu dan berprestasi akademik serta non akademik sebagai bekal melanjutkan ke pendidikan yang lebih tinggi dan hidup mandiri.

2. Terbentuknya pribadi yang berakhlak mulia, disiplin dan bertakwa kepada Allah SWT.

3. Terbentuknya pribadi yang cerdas dan berwawasan luas, serta mampu mengaktualisasikan diri kepada masyarakat.

Usaha dalam mewujudkan suatu visi tentunya harus adanya misi yang dilakukan oleh sekolah. Diantara misi tersebut ialah sebagai berikut:

1. Guru menyambut siswa setiap hari

2. Guru memberikan kosa kata bahasa Inggris kepada siswa setiap hari

3. Melaksanakan evaluasi hasil kegia-tan siswa setiap minggu

4. Melaksanakan pembiasaan siswa untuk mengucapkan salam kepada guru pada saat memasuki ruangan belajar dan ruangan lainnya.

5. Melaksanakan kegiatan kebersihan di lingkungan madrasah secara bersama-sama siswa setiap hari sabtu.

Selain visi dan misi yang dibentuk oleh sekolah, secara rinci pun MTs Jagat Raya telah mengidentifikasi beberapa tujuan dari visi dan misi yang telah dibuat. Diantara tujuan tersebut yaitu:

1. Meningkatkan kualitas dan kuantitas lulusan yang dapat diterima di lembaga pendidikan jenjang yang lebih tinggi.

2. Meningkatkan potensi akademik dan non akademik peserta didik.

3. Membekali keterampilan hidup yang dapat dimanfaatkan oleh peserta didik dalam kehidupan sehari-hari.

4. Mengaktualisasikan kehidupan yang religius di lingkungan madrasah yang ditandai dengan perilaku sholih, ikhlas, tawadhu, kreatif dan mandiri.

5. Membekali wawasan bahasa Inggris peserta didik dalam menghadapi era globalisasi dan kemajuan teknologi.

6. Memfasilitasi pengembangan profesi pendidik dan tenaga kependidikan.

7. Meningkatkan pelayanan prima dan kemampuan guru dalam pembelajaran.

8. Meningkatkan standar ketuntasan belajar, prestasi dan hasil ujian nasional setiap tahunnya.

9. Meningkatkan kemampuan guru dan 
siswa dalam pemanfaatan teknologi sebagai sumber belajar.

10. Mengembangkan berbagai wadah/ program penghayatan dan pengalaman agama.

Melakukan sebuah strategi sumber daya manusia, harus disesuaikan dengan visi dan misi yang dibuat oleh sekolah. Adapun cakupan dari strategi sumber daya manusia diantaranya ialah: visi dan misi sekolah, peraturan-peraturan yang ada di sekolah, rekrutmen guru dan karyawan, serta ujian masuk sekolah bagi siswa SD, pelatihan guru, serta program-program kerja yang telah dibuat oleh kepala sekolah.

Dalam menunjang visi dan misi sekolah, ada beberapa program kerja yang telah disusun oleh kepala sekolah beserta guruguru yang ada di MTs Jagat Raya. Berikut beberapa program kerja pada tahun 2016/2017. Penyusunan program kerja telah dilakukan secara sistematis yaitu dengan menyusun program kerja jangka pendek, mengah, dan jangka panjang. hal tersebut sesuai dengan pendapat dari Hamiyah dan Jauhar (2015:38) menyatakan bahwa suatu program kerja harus disesuaikan dengan misi yang akan dicapai serta disusun secara sistematis (jangka pendek, mengah, dan jangka panjang). deskripsi program kerja jangka pendek yaitu program kerja mencakup pada program kerja harian, mingguan, dan bulanan, sedangkan program kerja jangka mengah yaitu program kerja setiap satu semester atau selama enam bulan. Program kerja jangka panjang yaitu program kerja yang dilakukan selama dua semester atau satu tahun.

Adapun program kerja jangka pendek dibagi menjadi tiga. Yaitu program kerja harian, mingguan, dan bulanan. Adapun program kerja tersebut dapat digambarkan melalui tabel berikut:

Tabel 1 Program Kerja

\begin{tabular}{|c|c|}
\hline $\begin{array}{c}\text { Jenis Program } \\
\text { Kerja }\end{array}$ & Keterangan \\
\hline $\begin{array}{lr}\text { Memeriksa daftar } \\
\text { hadir guru dan } \\
\text { tenaga } \\
\text { kependidikan }\end{array}$ & terlaksana \\
\hline $\begin{array}{ll}\text { Mengatur } & \text { dan } \\
\text { memeriksa } \\
\text { kegiatan } 9 \mathrm{~K} \quad \text { di } \\
\text { Madrasah }\end{array}$ & Terlaksana \\
\hline $\begin{array}{l}\text { Memeriksa } \\
\text { program } \\
\text { pengajaran }\end{array}$ & Tidak konsisten \\
\hline $\begin{array}{l}\text { Menyelesaikan } \\
\text { administratif guru }\end{array}$ & Terlaksana \\
\hline $\begin{array}{l}\text { Mengatasi } \\
\text { hambatan terhadap } \\
\text { berlangsungnya } \\
\text { proses belajar } \\
\text { mengajar }\end{array}$ & Tidak konsisten \\
\hline $\begin{array}{l}\text { Mengatasi kasus } \\
\text { yang terjadi pada } \\
\text { hari ini }\end{array}$ & Terlaksana \\
\hline $\begin{array}{l}\text { Memeriksa segala } \\
\text { sesuatu menjelang } \\
\text { kegiatan madrasah } \\
\text { selesai }\end{array}$ & Terlaksana \\
\hline $\begin{array}{l}\text { Melaksanakan } \\
\text { supervisi kegiatan } \\
\text { belajar mengajar }\end{array}$ & Tidak konsisten \\
\hline $\begin{array}{l}\text { Melaksanakan } \\
\text { upacara bendera } \\
\text { setiap hari senin }\end{array}$ & Terlaksana \\
\hline $\begin{array}{l}\text { Melaksanakan } \\
\text { senam setiap } \\
\text { minggu }\end{array}$ & Terlaksana \\
\hline $\begin{array}{l}\text { Mengadakan rapat } \\
\text { mingguan }\end{array}$ & - \\
\hline $\begin{array}{l}\text { Memeriksa agenda } \\
\text { dan menyelesaikan } \\
\text { surat-surat }\end{array}$ & terlaksana \\
\hline $\begin{array}{l}\text { Memeriksa } \\
\text { keuangan } \\
\text { madrasah }\end{array}$ & terlaksana \\
\hline $\begin{array}{l}\text { Mengatur } \\
\text { penyediaan }\end{array}$ & terlaksana \\
\hline
\end{tabular}




\begin{tabular}{|l|l|}
\hline $\begin{array}{l}\text { perlengkapan } \\
\text { kantor madrasah }\end{array}$ & \\
\hline $\begin{array}{l}\text { Mlaksanakan } \\
\text { administratif } \\
\text { keuangan }\end{array}$ & terlaksana \\
\hline $\begin{array}{l}\text { Melaksanakan } \\
\text { pemeriksaan umum }\end{array}$ & terlaksana \\
\hline
\end{tabular}

\begin{tabular}{|l|l|}
\hline Evaluasi & terlaksana \\
\hline $\begin{array}{l}\text { Penyelenggaraan } \\
\text { penutupan buku } \\
\text { dan melaksanakan } \\
\text { Ujian Nasional } \\
\text { (UN) }\end{array}$ & \\
\hline $\begin{array}{l}\text { Kegiatan kenaikan } \\
\text { kelas dan kelulusan }\end{array}$ & terlaksana \\
\hline $\begin{array}{l}\text { Menyusun rencana } \\
\text { keuangan terlaksana }\end{array}$ & \\
\hline $\begin{array}{l}\text { Pembuatan laporan } \\
\text { akhir } \\
\text { pelajaran tahun }\end{array}$ & terlaksana \\
\hline $\begin{array}{l}\text { melaksanakan } \\
\text { kegiatan siswa } \\
\text { penerimaan } \\
\text { baru terlaksana }\end{array}$ & \\
\hline $\begin{array}{l}\text { Merencanakan } \\
\text { kegiatan kebutuhan } \\
\text { guru setiap mata } \\
\text { pelajaran }\end{array}$ & \\
\hline $\begin{array}{l}\text { Pembagian tugas } \\
\text { mengajar }\end{array}$ & terlaksana \\
\hline $\begin{array}{l}\text { Menyusun program } \\
\text { pengajaran, jadwal } \\
\text { pelajaran, } \\
\text { kalender } \\
\text { pendidikan }\end{array}$ & Terlaksana \\
\hline $\begin{array}{l}\text { Menyusun } \\
\text { kebutuhan buku } \\
\text { pelajaran dan buku } \\
\text { pegangan guru }\end{array}$ & \\
\hline $\begin{array}{l}\text { Menyusun } \\
\text { kelengkapan } \\
\text { pelajaran }\end{array}$ & \\
\hline Mengadakan rapat & terlaksana \\
\hline
\end{tabular}

Berdasarkan tabel data mengenai kegiatan program kerja dan keterangannya yang terlaksana atau masih jarang terlaksana, untuk mewujudkan program kerja tersebut, tentunya membutuhkan suatu konsistensi dan komitmen dari guru. Pada peningkatan komitmen seorang guru, harus dibutuhkan suatu strategi dari pemimpin atau kepala sekolah. Merujuk pada penelitian dari Niloufar (2011) mengenai komitmen guru, ada beberapa hal yang mempengaruhi komitmen seorang guru. Diantaranya yaitu: faktor ekonomi, hubungan internal di sekolah maupun eksternal dengan masyarakat, faktor sekolah, pengetahuan guru, dan karakter orang masing-masing.

Strategi sumber daya manusia bukan hanya sampai pada penerapan program kerja saja. Strategi dalam meningkatkan kualitas sumber daya manusia pun dimulai dari proses rekrutmen guru. Proses rekrutmen yang dilakukan oleh kepala sekolah MTs Jagat Raya dilakukan pada tahun 2008 dengan merekrut guru honorer dan meminta bantuan kepada MTs Negeri untuk membantu mengajar di MTs Jagat Raya. Proses rekrutmen tidak ada seleksi. Sejauh ini, jumlah guru sebanyak 16 guru. Setelah dilakukannya rekrutmen, penempatan guru disesuaikan dengan latar belakang pendidikan, dan berdasarkan pertimbangan ijazahnya.

Setelah guru ditetapkan dalam mengajar, perlu adanya pelatihan yang ditujukan oleh guru. Hal tersebut ditujukan agar guru-guru dapat memahami tugas dan visi misi dari sekolah. Sejalan dengan pendapat dari Shawn Doyle (2006:2) menyatakan bahwa tujuan dari pelatihan adalah sebagai peningkatan performance dari guru. Performanceatau kinerja guru ialah hal yang sangat krusial untuk meningkatkan kualitas sekolah, dan salah 
satu sebagai upaya peningkatan kinerja guru ialah dengan melakukan pelatihan.

Adapun strategi yang dilakukan oleh kepala sekolah MTs Jagat Raya dalam melaksanakan pelatiihan ialah dengan mengikut sertakan guru pada pelatihan resmi yang diadakan oleh pemerintah. Selebihnya, untuk pelatihan yang berbayar jarang dilakukan, dan hanya ditujukan kepada guru yang sukarela untuk mengikuti pelatihan berbayar tersebut. Hal tersebut dikarenakan tidak adanya dana dari sekolah setelah dilakukannya pelatihan, bukan hanya saja berhenti pada saat pelatihan dan dokumen-dokumen hasil pelatihan. Evaluasi merupakan suatu hal yang tidak pernah lepas dari kegiatan pelatihan. Pihak MTs Jagat Raya telah melakukan hasil evaluasi hanya dengan dokumen-dokumen yang ada dari hasil pelatihan. Akan tetapi, masalahnya masih tetap sama. Yaitu tidak berpengaruh cukup signifikan terhadap kinerja dan motivasi seorang guru. Justru, hal tersebut merupakan masalah krusial bagi MTs Jagat Raya.

Upaya dalam meningkatkan motivasi guru, bisa dilakukan strategi dengan memberikan tambahan gaji, dan pujian pada setiap pencapaian dan prestasi seorang guru. Upaya tersebut juga dapat mempengaruhi suatu komitmen guru, dan komitmen guru memiliki pengaruh kuat dengan fokus guru pada pelajaran yang diampunya (Madiha dan Marwan,2012). Lebih jelas menurut Madiha dan Marwan, salah satu hal yang dapat meningkatkan komitmen guru diantaranya yaitu: persamaan pemahaman mengenai visi dan misi sekolah, serta adanya penghargaan atas prestasi guru dan adanya hukuman atau peraturan terhadap guru agar dapat bertanggungjawab dan menumbuhkan komitmen.

Berdasarkan data kuesioner yang disebarkan kepada sepuluh guru MTs Jagat Raya mengenai strategi kepala sekolah dalam hal peningkatan komitmen guru, seperti: pemberian hadiah, pemberian motivasi pada guru, dan pemberian hukuman atau peraturan yang diberlakukan. Seluruh guru menyatakan bahwa belum pernah ada hadiah untuk guru yang memiliki prestasi. Hal tersebut perlu ditingkatkan agar menjadi cambuk bagi guru termotivasi dan terus berkomitmen untuk melaksanakan tugasnya. Begitupun juga dengan fungsi dari peraturan dan hukuman yang perlu diterapkan untuk guru-guru di sekolah. MTs Jagat Raya sendiri belum menerapkan peraturan tegas dan hukuman tegas bagi guru yang melanggar peraturan. Adanya suatu peraturan dan hukuman yang diberlakukan, guna untuk meningkatkan kinerja dan tanggung jawab dari guru.

Pada penelitian ini, peneliti pun menanyakan mengenai naik turunnya motivasi guru dalam kegiatan belajar mengajar. Seluruh responden menjawa bahwa keadaan motivasi mereka sedang turun ketika gaji sering telat. Bahkan, ada yang mengemukakan bahwa guru kurang merasa puas dengan gaji yang didapatkan. Untuk menanggulangi hal ini, kepala sekolah bisa melakukan strategi seperti 
yang telah disebutkan diatas. Yaitu pemberian hadiah kepada guru yang berprestasi, serta membuat peraturan dan hukuman yang konsisten. Akan tetapi, ada strategi kepala sekolah dalam hal meningkatkan motivasi guru yaitu dengan memberikan arahan motivasi kepada guruguru setiap evaluasi pembelajaran. Strategi ini bisa dijadikan suatu cambuk bagi guru untuk meningkatkan motivasinya.

Berikut analisis SWOT (Strength, Weakness, Opportunities dan Threats) berdasarkan hasil wawancara dan observasi pada MTs Jagat Raya:

a. Kekuatan (Strength): - Banyak kegiatan-kegiatan spiritualitas pada MTs Jagat Raya. Seperti: kegiatan rutin sholat Dhuha dan pembacaan surah Yasin sebelum melakukan pembelajaran.

- Memiliki beberapa guru yang berkomitmen tinggi.

- Masyarakat mulai percaya pada sekolah-sekolah islami.

Strategi untuk memperkuat kekuatan yang dimiliki oleh MTs Jagat Raya:

- Mempertahankan kegiatan yang menumbuhkan spiritualitas siswa.

- Mengembangkan pendidikan karakter melalui kegiatan spiritualitas.

- Memberikan insentif atau hadiah kepada guru yang memiliki prestasi dan berkomitmen tinggi.

- Meningkatkan kepercayaan masyarakat dengan membuat suatu acara yang melibatkan masyarakat dan civitas akademik MTs Jagat Raya.

b. Kelemahan (Weakness):

- Kurangnya sarana pra sarana.

- Tidak mempunyai donatur. Hanya mengandalkan dana BOS.

- Motivasi siswa mayoritas rendah untuk belajar.

- Ada beberapa guru yang mengajar di tempat lain. Sehingga harus membagi waktu dan fokus untk MTs Jagat Raya.

Strategi untuk mengatasi kelemahan (Weakness):

- Pemimpin atau kepala sekolah harus melakukan kerjasama atau mencari donatur agar dapat membantu memenuhi sarana pra sarana sekolah.

- Memberikan hadiah kepada siswa yang memiliki motivasi tinggi dalam belajar. $\mathrm{Hal}$ ini bertujuan untuk memotivasi siswa yang lain.

- Memberikan motivasi dan melakukan pertemuan secara berkala dalam mengevaluasi kinerja guru.

c. Kesempatan (Opportunities):

- Memiliki siswa berprestasi di beberapa bidang ekstrakurikuler dan akademik.

- Telah menjalin kerjasama dengan beberapa sekolah dasar guna sebagai startegi mendapatkan 
siswa baru.

- Adanya dukungan dari masyarakat dalam eksistensi MTs Jagat Raya.

- Memiliki beberapa siswa dari luar daerah dikarenakan MTs Jagat Raya menyediakan asrama.

Strategi untuk meningkatkan kesempatan:

- Melatih dan memfokuskan siswa yang berprestasi di bidangnya, serta memberikan motivasi terus menerus.

- Memperluas jaringan kerja sama dengan berbagai sekolah dasar. Bukan hanya sekolah dasar di sekitar MTs Jagat Raya.

- Memperhatikan komunitas atau masyarakat disekitar MTs Jagat Raya dengan melakukan berbagai hal: membuat program pengajian dengan masyarakat, mengadakan bakti sosial kepada masyarakat sekitar.

- Memberikan pelayanan yang bagus kepada siswa dari luar daerah. Agar mereka dapat menjadi duta MTs Jagat Raya guna mempromosikan Mts Jagat Raya di daerahnya.

d. Tantangan (Threats):

- Banyak SMP swasta yang ada di sekitar MTs Jagat Raya. Sehingga persaingan dalam mencari siswa dan menjadi sebuah tantangan kedepan.

- Mayoritas siswa berasal dari keluarga menengah kebawah. Sehingga membutuhkan keterampilan khusus jika tidak dilanjutkan ke jenjang berikutnya.

Strategi untuk mengatasi tantangan:

- Melakukan iklan sekolah atau startegi humas dengan cara yang unik dan berbeda dengan yang lainnya.

- Melakukan kerjasama dengan sekolah dasar yang ada di luar daerah.

- Membekali siswa dengan keterampilan. Seperti mengadakan ekstrakurikuer menjahit, kerajinan, atau yang lainnya.

\section{DAMPAK STRATEGI SUMBER DAYA MANUSIA TERHADAP PERKEMBANGAN SEKOLAH}

Adapun strategi-strategi pengelolaan sumber daya manusia yang dilakukan oleh kepala sekolah tujuannya ialah untuk mengembangkan sekolah sehingga dapat mencapai visi dan misi sekolah. Pada bagian ini, peneliti memaparkan beberapa dampak strategi sumber daya manusia terhadap perkembangan sekolah yang meliputi: jumlah siswa selama lima tahun terakhir, nilai UN siswa, dan prestasiprestasi yang telah didapatkan oleh MTs mempertahankan eksistensi Jagat Raya. 
Mengingat bahwa MTs Jagat Raya merupakan sekolah swasta menengah pertama yang berbasis agama islam yang memiliki pembayaran yang masih cukup minim dan kecil jika dibandingkan dengan sekolah-sekolah swasta lainnya. Mempertahankan sebuah sekolah swasta untuk tetap terjaga eksistensinya dengan meningkatnya jumlah siswa merupakan suatu hal yang sangat krusial dan cukup berat bagi sekolah swasta di desa. Terlebih saat ini banyak dibukanya sekolah-sekolah swasta baru di desa yang mengakibatkan meningkatnya kompetisi antar sekolah. Tentunya, hal ini tidaklah terlepas dari strategi kepala sekolah dalam pengembangan sumber daya manusia. Berikut jumlah siswa selama lima tahun terakhir di MTs Jagat Raya.

Tabel 2 Jumlah Siswa Selama Lima Tahun Terakhir

\begin{tabular}{|cc|}
\hline TAHUN & JUMLAH \\
\hline $2013 / 2014$ & $\mathbf{1 7 9}$ \\
\hline $2014 / 2015$ & $\mathbf{1 7 6}$ \\
\hline $2015 / 2016$ & $\mathbf{1 5 3}$ \\
\hline $2016 / 2017$ & $\mathbf{1 5 1}$ \\
\hline $2017 / 2018$ & $\mathbf{1 4 8}$ \\
\hline
\end{tabular}

Berdasarkan data tersebut, terlihat bahwa jumlah siswa selama lima tahun terakhir semakin menurun. Hal tersebut dikarenakan beberapa faktor. Diantaranya adalah: faktor panitia penerimaan siswa baru, strategi yang berbeda diterapkan oleh masing-masing panitia penerimaan siswa baru, faktor kerja sama yang terlalu minim, dan banyaknya sekolah swasta di desa, sehingga terjadi tumpang tindih dalam mencari siswa.

Adapun strategi yang diterapkan oleh MTs Jagat Raya dalam melakukan penerimaan peserta didik baru yaitu dengan membentuk panitia penerimaan peserta didik baru. Akan tetapi, pada empat tahun terakhir ini, terjadi beberapa pergeseran kebijakan, serta kerja sama hanya dilakukan dengan sekolah-sekolah dasar disekitar desa Kedongdong saja. Serta ada beberapa kekurangan lainnya yaitu penyebaran brosur pembukaan peserta didik baru lebih lambat jika dibandingkan dengan sekolah swasta lain yang ada di sekitar desa Kedongdong. Berdasarkan kekurangan-kekurangan strategi tersebut, dapat diperbaiki lagi dalam perencanaan pembukaan pendaftaran peserta didik baru.

Adapun proses seleksi siswa di MTs Jagat Raya masih belum adanya seleksi yang ketat. Sehingga masih mudah dan hampir semua pendaftar diterima di MTs Jagat Raya. Dalam mengelola siswa pada suatu proses kegiatan belajar mengajar pun perlu adanya strategi yang tepat dan sesuai, untuk mewujudkan siswa yang berprestasi dan bertakwa, kepala sekolah MTs Jagat Raya membuat program beberapa ekstrakurikuler (pramuka, PMR, dan silat) serta membiasakan siswa untuk membaca Al-Qur'an sebelum masuk jam pelajaran. Semua kegiatan tersebut berjalan lancar. Akan tetapi, ada beberapa ekstrakurikuler yang kurang berjalan akhir-akhir ini. adapun output siswa MTs Jagat Raya dapat dilihat dari rata-rata nilai Ujian Nasional pada tahun 
2016/2017 dengan rata-rata nilai ujian nasional yaitu 282,1. Pada tahun 2016 dan 2017, prestasi akademik maupun non akademik MTs Jagat Raya meningkat, dengan memenangkan lomba olimpiade matematika di tingkat kabupaten dengan memperoleh juara dua.

\section{KESIMPULAN DAN SARAN}

\section{Kesimpulan}

Adapun strategi sumber daya manusia yang diterapkan oleh kepala sekolah MTs Jagat Raya ialah dengan menerapkan visi dan misi, merancang program kerja berdasarkan visi dan misi yang telah dibuat, serta melakukan rekrutmen guru dengan membuka lowongan dan meminta bantuan guru pengajar di sekolah negeri untuk mengajar di MTs Jagat Raya. Dalam pengelolaannya, kepala sekolah MTs jagat Raya melakukan pelatihan kepada guru-guru dan memberikan motivasi. Akan tetapi, kurangnya penghargaan kepada guru berprestasi dan belum adanya peraturan dan hukuman bagi guru yang melanggar secara konsisten.

Dampak dari strategi sumber daya manusia yang dilakukan oleh kepala sekolah menyebabkan beberapa perubahan terhadap perkembangan sekolah. Seperti jumlah siswa dan nilai Ujian Nasional, serta prestasi-prestasi yang telah didapatkan oleh MTs Jagat Raya. Pada lima tahun terakhir, jumlah siswa MTs Jagat Raya semakin menurun. Hal tersebut dikarenakan beberapa hal, yaitu berubahnya panitia penerimaan peserta didik baru sehingga terdapat perubahan kebijakan dan semakin banyaknya sekolah-sekolah swasta disekitar. Adapun rata-rata nilai Ujian Nasional siswa MTs Jagat Raya yaitu 282,1.

\section{Saran}

Berdasarkan hasil penelitian ini, ada beberapa saran yang diajukan oleh peneliti. Diantaranya yaitu:

(1) Perlu adanya perbaikan bagi strategi yang dilakukan oleh MTs Jagat Raya dalam hal peningkatan komitmen guru.

(2) Perlu adanya peningkatan kerja sama dengan pemerintah daerah dan masyarakat sekitar.

(3) Pemerintah harus lebih memperhatikan kulaitas sekolah swasta sebagai sarana pemerataan sekolah.

\section{DAFTAR PUSTAKA}

Armstrong, Michael. 2006. Strategic Human Resource Management: A Guide To Action. USA: Thomson-Shore, Inc

Collings, David and Geoffrey Wood. 2009. Human Resources Management: $A$ Critical Approach.USA: Routledge

Doyle, Shawn.2006. The Manager's Pocket Guide To Training. Canada: HRD Press, Inc

Hamiyah, Nur dan Mohammad Jauhar. 2015. Pengantar Manajemen Pendidikan Di Sekolah. Jakarta: Prestasi Pustaka Jakarta

Mahapatro.2010.Human Resources Management. New Delhi: New Age International (P) Ltd.,Publisher

Mohammadtaheri, Niloufar. 2011. The Study Of Effective Factors On The Teachers' Work Commitment In High Schools. International Conference on 
Educational and Educational Psychology, 29 (2011), 1524 - 1530.

Nur'aini, Fajar. 2016. Teknik Analisis SWOT: Pedoman Menyusun Strategi yang Efektif dan Efisien serta Cara Mengelola Kekuatan dan Ancaman.Yogyakarta: Quadrant.

Shah, Madiha dan Marwan Abualrob. 2012. Teacher Collegiality And Teacher Professional Commitment In Public Secondary Schools In Islamabad, Pakistan. Procedia Social and Behavioral Science, 46 (2012), 950954.
Torrington, Derek, Laura Hall and Stephen Taylor. 2008. Human Resource Management. England: Pearson Education Limited

Torrance, Harry. 2007. Education And Theory: Strangers In Paradigms. New York: Gary Thomas

kabar-cirebon.com (diakses pada tanggal 3 Januari 2018)

detik.com (diakses pada tanggal 3 Januari 2018) 